\title{
Persepsi Mahasiswa Terhadap Perkuliahan Daring Di Masa Pandemi Covid 19
}

\author{
Muhammad Akbar Syafruddin, Ikadarny, Andi Sahrul Jahrir \\ Program Studi Pendidikan Jasmani, Kesehatan, dan Rekreasi STKIP YPUP Makassar \\ akbarsyafruddin007@gmail.com
}

Received: Januari 2021; Accepted: Februari 2021; Published: Maret 2021

Ed: Maret 2021; 8(1): 8-15

\begin{abstract}
Abstrak
Tujuan penelitian, untuk mengetahui persepsi mahasiswa Pendidikan Olahraga terhadap perkuliahan daring selama pandemi Covid-19. Metode dalam penelitian ini bersifat desktiptif kuantitatif untuk mengetahui persepsi mahasiswa Pendidikan Jasmani, Kesehatan, dan Rekreasi STKIP YPUP Makassar. Teknik pengumpulan data dalam penelitian ini menggunakan survey dengan memanfaatkan media angket yang disebarkan dengan menggunakan google form. Sampel dalam penelitian ini berjumlah 35 orang mahasiswa dengan menggunakan teknik random sampling. Hasil penelitian ini menunjukkan sebanyak 29 orang mahasiswa atau sebesar $83 \%$ yang menyatakan setuju, sebanyak 1 orang mahasiswa atau sebesar $3 \%$ menyatakan sangat setuju, sebanyak 2 orang mahasiswa atau sebesar 6\% menyatakan kurang setuju, dan sebanyak 3 orang mahasiswa atau sebesar $8 \%$ menyatakan tidak setuju dengan penerapan perkuliahan daring di masa pandemi Covid-19 ini. Sehingga dapat disimpulkan bahwa mahasiswa setuju dengan penerapan perkuliahan daring dimasa pandemi Covid-19 ini.
\end{abstract}

Kata Kunci: Persepsi Mahasiswa, Perkuliahan Daring, Pandemi Covid-19.

\begin{abstract}
The aim of the study was to determine the physical education students' perception about online classes during the Covid-19 pandemic. The method used in this study is descriptive quantitative to determine students' views on sports, health and entertainment STKIP YPUP Makassar. The data collection technique used multimedia questionnaires distributed using Google Forms. The sample of random sampling techniques used in this study were 35 students. The results of this study showed that 29 students or $83 \%$ agree, 1 student or 3\% strongly agree, 2 students or $6 \%$ disagree and 3 students or the 8\% disagree to apply for online classes during this period 2019 Coronavirus pandemic. Therefore, it can be concluded that the students agreed to implementation of online classes during the Covid-19 pandemic.
\end{abstract}

Keywords: Student's Perception, Online Lecture, Covid-19 Pandemic.

\section{PENDAHULUAN}

Sebagaimana disebutkan dalam alinea IV Pembukaan Undang-Undang Dasar Negara Republik Indonesia Tahun 1945, salah satu tujuan negara Indonesia adalah mencerdaskan kehidupan bangsa. Dalam kaitannya dengan pendidikan kehidupan suatu negara, hal ini dapat dicapai melalui pendidikan formal atau informal. Nurkholis (2013: 25) Pendidikan adalah suatu proses yang meliputi seluruh isi realitas material dan spiritual dan tiga aspek individu, masyarakat atau komunitas nasional, yang membantu untuk menentukan sifat, nasib dan bentuk manusia, dan sosial. Pendidikan bukan sekedar pembelajaran. Ini adalah proses yang mencakup semua transfer pengetahuan, transformasi nilai dan pembentukan kepribadian. 
Dengan demikian, pendidikan akan memainkan peran penting dalam kehidupan individu, mempersiapkan mereka untuk menghadapi tantangan yang lebih besar dan lebih kompetitif di masa depan. Pendidikan dirancang untuk memberikan pemahaman dan meningkatkan prestasi siswa ketika siswa menjadi cukup dewasa untuk mengembangkan bakat, peluang, dan keterampilan mereka dalam hidup. Pendidikan juga dapat menjadi faktor penentu nilai dan kualitas hidup seseorang. Dilihat dari peran pendidikan yang sangat besar dalam kehidupan kita, ada baiknya kita dapat memajukan pendidikan di negeri ini dan membawa banyak manfaat bagi kita semua.

Seperti yang tertuang dalam undang-undang Pasal 3 No. 20 Tahun 2003 tentang Sistem Pendidikan Nasional, tujuan akhir pendidikan (nasional) pada dasarnya adalah meningkatkan kualitas sumber daya manusia (SDM). Untuk mewujudkannya diperlukan pendidikan yang berkualitas. Begitu pula di masa pandemi Covid-19 ini, seluruh pihak dituntut untuk tetap menjalankan proses pendidikan ditengah keterbatasan yang ada.

Di era modern saat ini, pelaku di dunia pendidikan dituntut untuk dapat melaksanakan setiap proses pembelajaran dalam situasi dan kondisi apapun. Mewabahnya virus covid-19 di Indonesia sejak awal maret 2020, akhirnya memaksa pemerintah untuk memberlakukan aturan Pembatasan Sosial Berskala Besar (PSBB) di sebagian besar wilayah di Indonesia. Pemberlakuan aturan ini juga secara otomatis turut mendorong terjadinya perubahan sistem pendidikan untuk melaksanakan proses pendidikan secara jarak jauh atau dengan memanfaatkan media online.

Adanya perubahan proses pembelajaran di tengah pandemi covid-19 ini tentunya menjadi tantangan tersendiri bagi seluruh pihak yang terlibat di dunia pendidikan. dari hasil penelitian yang dilakukan oleh Damanik (2019:46-52) di sebuah perguruan tinggi swasta, bahwa lingkungan belajar memiliki pengaruh yang signifikan terhadap motivasi belajar. Begitu pula di masa pandemi Covid-19 ini lingkungan belajar yang tadinya berada di kampus bersama dosen dan teman-teman, mengalami perubahan yang mengharuskan proses pembelajaran hanya dilaksanakan di rumah.

Pandemi covid-19 yang terjadi kurang lebih dua tahun belakangan ini, telah membawa perubahan besar bagi dunia, tidak terkecuali Indonesia. Menurut (Rahcmat, 2020) penyebaran virus corona menjadi penyebab angka kematian yang paling tinggi untuk saat ini. Berbagai negara telah menerapkan social distancing (pembatasan jarak sosial) yang dirancang untuk mengurangi interaksi antara orang-orang dalam komunitas yang lebih luas. Hal ini membawa dampak besar bagi seluruh sektor dalam kehidupan khususnya di sektor pendidikan.

Pembelajaran yang biasanya dilakukan dengan tatap muka beralih menjadi pembelajaran online. Hal teresebut dilakukan agar proses pembelajaran tetap dapat dilaksanakan melalui pemanfaatan berbagai media pembelajaran online dengan menggunakan perangkat komputer atau gadget yang saling terhubung antara mahasiswa dan doesn, sehingga melalui pemanfaatan teknologi tersebut proses belajar mengajar bisa tetap dilaksanakan dengan baik (Pakpahan, 2020).

Perubahan sistem pembelajaran ini membawa dampak besar dalam dunia pendidikan terkhusus bagi mahasiswa pendidikan jasmani yang seolah dituntut untuk menyesuaikan diri untuk melaksanakan pembelajaran di rumah. Terlebih sebagian besar mahasiswa pendidikan jasmani tidak pernah merasakan pembelajaran secara online, serta sebagian besar proses perkuliahannya dilaksanakan di lapangan. Hal ini menjadi sebuah hambatan pada proses pembelajaran yang dapat mempengaruhi psikologis dan kebiasaaan mahasiswa dalam perkuliahan. Hal ini mengakibatkan proses pembelajaran menjadi kurang efisien, konsentrasi siswa menjadi berkurang dan sulitnya dalam memahami, bertanya jawab serta berdiskusi tentang materi yang dipelajari selama pembelajaran online (Purwanto, 2020). 
Dengan berbagai permasalah di atas, maka peneliti tertarik untuk mengetahui sudut pandang mahasiswa terhadap proses pembelajaran daring yang diterapkan selama masa pandemi Covid-19 ini melalui penelitian yang berjudul "Persepsi Mahasiswa terhadap Pembelajaran Daring di Masa Pandemi Covid-19”. Adapun tujuan dari penelitian ini adalah untuk mengetahui bagaimana pandangan mahasiswa terhadap pelaksanaan perkuliahan daring, sehingga dapat dijadikan sebagai bahan masukan bagi semua pihak yang terlibat demi tercapainya tujuan pendidikan di masa pandemi Covid-19 ini.

\section{TINJAUAN PUSTAKA}

Persepsi menurut Liliweri (2011:153) merupakan proses dimana individu memilih, mengorganisasi dan menginterpretasi apa yang dibayangkan tentang dunia di sekelilingnya. Sedangkan persepsi dalam kamus diartikan sebagai proses pemahaman ataupun pemberian makna atas suatu informasi terhadap stimulus. Stimulus diperoleh dari proses penginderaan terhadap objek, peristiwa atau hubungan-hubungan antar gejala yang selanjutnya diproses oleh otak (Umam, 2010). Jadi dapat dikatakan persepsi adalah pandangan, tanggapan, atau pesan yang diperoleh seseorang berdasarkan pengalaman yang telah dialami.

Pembelajaran daring adalah sistem pembelajaran yang penerapannya berbasis web. Model pembelajaran jarak jauh online diawali dengan perencanaan yang baik, kemudian cara materi pembelajaran disampaikan (delivery content) kepada pembelajar yang mengacu pada perancangan tersebut. Menurut Kenji Kaito (1998) ada 3 fungsi atau potensi online learning yang dapat dimanfaatkan dalam kehidupan sehari-hari yaitu sebagai alat komunikasi, alat mengakses informasi, dan alat pendidikan atau pembelajaran. (Munir, 2009:97). Jadi pembelajaran daring adalah proses pembelajaran yang dilaksanakan secara jara jauh dengan memanfaatkan media online sebagai penghubung.

Covid-19 merupakan suatu virus yang telah menjadi pandemi dan sangat mempengaruhi segala aktivitas di seluruh dunia. Masyarakat dunia heboh dengan adanya pandemi karena tidak hanya penyebarannya yang cepat dan meluas, karakternya yang membunuh dan jumlah kematian yang sangat besar dalam waktu singkat dapat terjadi (Yulianingsih \& Doby, 2020). Pada tanggal 11 Februari 2019 novel coronavirus (2019-nCov) oleh WHO mengumumkan adanya nama baru yaitu Coronavirus Disease (Covid-19). Penyebab oleh virus Severe Acute Respiratory Syndrome Coronavirus-2 (SARS-Cov-2). Direktur Jenderal WHO, Dr. Tedros Adhanom Ghebreyesus telah mengumumkan bahwa covid-19 adalah pandemi (Elvina, 2020) mengatakan "WHO has been assessing this outbreak around the clock and we are deeply concerned both by the alarming levels of spread and severity, and by the alarming levels of inaction. We have therefor made the assesement that covid-19 can be characterized as a pandemi" Pandemi pertama virus corona yang menimpa dunia dan meminta kepada seluruh Negara menindak dan mencegah penyebarannya.

\section{METODE}

Penelitian ini menggunakan metode deskriptif kualitatif yang bertujuan untuk memecahkan atau mengetahui masalah berdasarkan deskripsi dari responeden. Informasi yang diperoleh berasal dari keadaan sebenarnya yang dialami leh responden. Hasil yang diperoleh merupakan diskripsi hasil interpretasi. Penelitian ini bertujuan mengumpulkan informasi dari fenomena yang ada secara umum. Digunakan sebagai penjelasan atas perilaku dan sikap-sikap tertentu (W.Creswell, 2014). Yang menjadi sampel dalam penelitian ini adalah mahasiswa Penjaskesrek STKIP YPUP Makassar 
yang berjumlah 35 orang.. Teknik pengumpulan data dengan menggunakan instrument kuesioner. Kuesioner yang dibuat berpedoman pada skala likert. Skala likert merupakan skala yang digunakan untuk mengukur sikap, pendapat, dan persepsi seseorang atau sekelompok orang tentang fenomena sosial Sugiyono (2014: 134).

\section{HASIL DAN PEMBAHASAN}

Hasil penelitian yang telah dilakukan kepada 35 orang mahasiswa Penjaskesrek STKIP YPUP Makassar dapat dilihat di tabel dibawah ini :

Tabel 1. Hasil Persepsi Mahasiswa

\begin{tabular}{ll}
\hline \multicolumn{2}{c}{ Persepsi Mahasiswa } \\
\hline N & 35 \\
Range & 210 \\
Minimum & 100 \\
\hline Maksimum & 310 \\
Sum & 8723 \\
\hline Rata-rata & 249,23 \\
Standar Deviasi & 48,129 \\
\hline Varians & 2316,358 \\
\hline
\end{tabular}

Berdasarkan Tabel di atas dapat dijelaskan bahwa nilai range dalam penelitian ini sebesar 210, nilai tertinggi sebesar 310, nilai terendah sebesar 100, dan nilai rata-rata dari total 35 orang mahasiswa sebesar 249,23 poin.

Tabel 2. Data Hasil Penelitian Persepsi Mahasiswa

\begin{tabular}{|l|lcc|}
\hline No. & Sampel & Skor & Kategori \\
\hline 1. & Mahasiswa 1 & 285 & S \\
\hline 2. & Mahasiswa 2 & 236 & S \\
\hline 3. & Mahasiswa 3 & 246 & S \\
\hline 4. & Mahasiswa 4 & 276 & S \\
\hline 5. & Mahasiswa 5 & 310 & SS \\
\hline 6. & Mahasiswa 6 & 242 & S \\
\hline 7. & Mahasiswa 7 & 100 & TS \\
\hline 8. & Mahasiswa 8 & 123 & TS \\
\hline 9. & Mahasiswa 9 & 231 & S \\
\hline 10. & Mahasiswa 10 & 120 & TS \\
\hline 11. & Mahasiswa 11 & 248 & S \\
\hline 12. & Mahasiswa 12 & 225 & KS \\
\hline 13. & Mahasiswa 13 & 265 & S \\
\hline 14. & Mahasiswa 14 & 242 & S \\
\hline 15. & Mahasiswa 15 & 234 & S \\
\hline 16. & Mahasiswa 16 & 275 & S \\
\hline
\end{tabular}




\begin{tabular}{l|lcc|}
\hline 17. & Mahasiswa 17 & 254 & S \\
\hline 18. & Mahasiswa 18 & 276 & S \\
\hline No. & Sampel & Skor & Kategori \\
\hline 19. & Mahasiswa 19 & 231 & S \\
\hline 20. & Mahasiswa 20 & 187 & KS \\
\hline 21. & Mahasiswa 21 & 287 & S \\
\hline 22. & Mahasiswa 22 & 285 & S \\
23. & Mahasiswa 23 & 286 & S \\
24. & Mahasiswa 24 & 274 & S \\
\hline 25. & Mahasiswa 25 & 250 & S \\
\hline 26. & Mahasiswa 26 & 268 & S \\
27. & Mahasiswa 27 & 279 & S \\
\hline 28. & Mahasiswa 28 & 280 & S \\
\hline 29. & Mahasiswa 29 & 279 & S \\
\hline 30. & Mahasiswa 30 & 274 & S \\
\hline 31. & Mahasiswa 31 & 273 & S \\
\hline 32. & Mahasiswa 32 & 266 & S \\
\hline 33. & Mahasiswa 33 & 264 & S \\
\hline 34. & Mahasiswa 34 & 278 & S \\
\hline 35. & Mahasiswa 35 & 274 & S \\
\hline Rata-rata & $\mathbf{2 4 9 , 2 2 8 6}$ & \\
\hline
\end{tabular}

Setelah memperoleh data hasil penelitian terkait persepsi mahasiswa terhadap pembalajaran daring di masa pandemi ini, selanjutnya dilakukan pengkategorian untuk memudahkan dalam mendeskripsikan data dari responden.

Tabel 3. Pengkategorian Skor

\begin{tabular}{cc}
\hline Interval & Kategori \\
\hline $\mathbf{2 9 5 - 3 6 0}$ & Sangat Setuju \\
$\mathbf{2 2 7 - 2 9 4}$ & Setuju \\
$\mathbf{1 5 9 - 2 2 6}$ & Kurang Setuju \\
$\mathbf{9 0 - 1 5 8}$ & Tidak Setuju \\
\hline
\end{tabular}




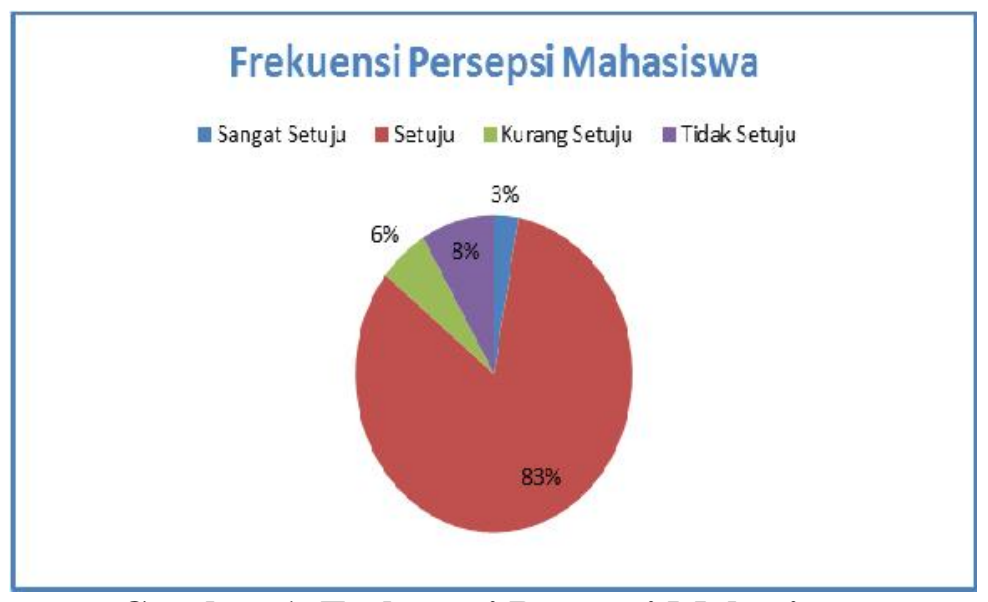

Gambar 1. Frekuensi Persepsi Mahasiswa

Berdasarkan diagram dan tabel pengkategorian di atas, dapat dinyatakan bahwa sebagian besar mahasiswa merasa setuju dengan dilaksanakannya pembelajaran daring di masa pandemi Covid-19 ini. Dari total 35 orang sampel (mahasiswa), sebanyak 29 orang mahasiswa atau sebesar $83 \%$ yang menyatakan setuju, sebanyak 1 orang mahasiswa atau sebesar 3\% menyatakan sangat setuju, sebanyak 2 orang mahasiswa atau sebesar $6 \%$ menyatakan kurang setuju, dan sebanyak 3 orang mahasiswa atau sebesar $8 \%$ menyatakan tidak setuju dengan penerapan pembelajaran daring di masa pandemi Covid-19 ini.

\section{PEMBAHASAN}

Dalam implementasi pembelajaran daring di rumah, salah satu keterbatasan dari penerapan ini adalah peralatan dan infrastruktur pendukung seperti laptop, komputer, telepon seluler, dan kemampuan internet. Hal tersebut sangat penting untuk menciptakan kondisi yang menguntungkan bagi mahasisiswa dalam proses perkuliahan. Pembelajaran tatap muka dianggap tertutup dan dipahami sebagai model tradisional, sehingga dibutuhkan fasilitas pembelajaran yang lebih baik dengan pemanfaatan teknologi informasi (Panigrahi, Srivastava, \& Sharma, 2018). Pendidikan tinggi pada masa WFH perlu melakukan penguatan pembelajaran secara daring (Darmalaksana, WhatsApp Kuliah Mobile , 2020). Pembelajaran secara daring telah menjadi tuntutan dunia pendidikan sejak beberapa tahun terakhir (He, Xu, \& Kruck, 2014).

Menurut (Aghajani \& Adloo, 2018) mahasiswa lebih menunjukkan sikap positif terhadap pembelajaran daring dibandingkan pembelajaran tatap muka. Lebih lanjut (Maha, Shazia, \& Jehan, 2016) menyatakan bahwa kalangan mahasiswa mendapat kepuasan dengan pelaksanaan pembelajaran daring. Banyaknya aplikasi online yang dapat digunakan dengan mudah dan gratis, seperti Google Classroom, Whatsapp, Quipper dan lain sebagainya (Abidah, Hidayaatullaah, Simamora, Fehabutar,\& Mutakinati, 2020) yang dapat mengirimkan pesan teks, gambar, video dan file lain(Kusuma, 2020) memberikan kemudahan bagi siswa dalam mengikuti proses pembelajaran daring di masa pandemi Covid-19 ini.

Dari penelitian yang telah dilakukan terkait persepsi mahasiswa Pendidikan Jasmani, Kesehatan, dan Rekreasi STKIP YPUP Makassar terhadap pembelajaran daring di masa pandemi ini menunjukkan bahwa sebanyak 29 orang mahasiswa atau sebesar $83 \%$ merasa setuju dengan diterapkannya proses perkuliahan daring di masa pandemi ini. Sehingga dapat diartikan bahwa mahasiswa merasa penerapan pembelajaran daring di masa pandemi ini memberikan kemudahan 
dan keamanan bagi mahasiswa dalam mengikuti proses perkuliahan. Hal ini sejalan dengan hasil penelitian yang dilaksanakan (Maulah \& Ummah, 2020), dimana penelitian tersebut menjelaskan bahwa pembelajaran daring menggunakan Whatsapp lebih efektif untuk digunakan. Banyaknya aplikasi pembelajaran daring yang dapat diakses dengan mudah, proses perkuliahan yang dapat dilakukan dimana saja, serta pengalaman belajar yang baru menjadi daya tarik tersendiri bagi mahasiswa.

Meskipun sebagian besar mahasiswa merasa setuju dengan pembelajaran daring ini, akan tetapi terdapat 5 orang mahasiswa atau sebesar $14 \%$ yang merasa tidak setuju dengan diterapkannya pembelajaran daring ini. Dibalik banyaknya kemudahan yang diberikan melalui pembelajaran daring, juga terdapat kekurangan yang tidak dapat terhindarkan khususnya bagi mahasiswa Pendidikan Jasmani, yang mana sebagian besar proses perkuliahannya selama ini dilakukan secara praktek atau tatap muka di lapangan. Hal tersebut sejalan dengan penelitian yang dilakukan oleh (Komarudin \& Prabowo, 2020) dimana penelitian tersebut menunjukkan bahwa pembelajaran daring dalam pendidikan jasmani kesehatan dan rekreasi belum efektif, lebih banyak menggunakan praktik untuk mengolah aktivitas fisik. Sehingga membuat terbatasnya komunikasi dan tercapainya pembelajaran terutama praktik lapangan. Dalam penelitian ini mahasiswa menggunakan gaya belajar semi dua arah dengan menggunakan video, yang kemudian mahasiswa memberikan pelaporan dalam bentuk video yang diupload dalam aplikasi google drive dosen. Keterbatasan kuota mahasiswa menjadi salah satu persepsi mahasiswa dalam melaksanakan perkuliahan daring, sinyal internet yang kurang lancar, banyak mahasiswa yang menggunakan perkuliahan dengan HP, selain itu persepsi mahasiswa terhadap perkuliahan daring akan lebih banyak tugas yang diberikan dibandingkan dengan perkuliahan secara tatap muka.

\section{KESIMPULAN}

Kesimpulan dalam penelitian ini adalah mahasiswa Pendidikan Jasmani, Kesehatan, dan Rekreasi STKIP YPUP Makassar setuju dengan penerapan pembelajaran daring di masa pandemi Covid-19 ini. Banyaknya media online yang dapat digunakan dalam proses perkuliahan seperti zoom, google meet, whatsapp, dan media online lainnya memberikan kemudahan dan keamanan bagi mahasiswa dalam mengikuti perkuliahan. Penerapan perkuliahan daring di masa pandemi merupakan salah satu jalan untuk memutus mata rantai penyebaran virus Covid-19 yang saat ini melanda Indonesia. Sehingga dapat dikatakan perkuliahan daring merupakan satu-satunya cara yang pailng efektif untuk diterapkan dalam proses perkuliahan di masa pandemi ini.

\section{DAFTAR PUSTAKA}

Alo Liliweri M.S, Komunikasi Serba Ada Dan Serba Makna Ed. 1, Cetakan ke (Jakarta: Kencana, 2011)

Abidah, A., Hidaayatullaah, H. N., Simamora, R. M., Fehabutar, D., \& Mutakinati, L. (2020). The Impact of Covid-19 to Indonesian Education and Its Relation to the Philosophy of "Merdeka Belajar." Studies in Philosophy of Science and Education, 1(1), 38-49. https://doi.org/10.46627/sipose.v1i1.9

Aghajani, M., \& Adloo, M. (2018). The Effect of Online Cooperative Learning on Students' Writing Skills and Attitudes through Telegram Application . International Journal of Instruction.

Damanik, B. E. (2019). Pengaruh Fasilitas Dan Lingkungan Belajar Terhadap Motivasi Belajar. Publikasi Pendidikan, 9(1), 46. https://doi.org/10.26858/publikan.v9i1.7739

Darmalaksana, W. (2020). WhatsApp Kuliah Mobile . Fakultas Ushuluddin UIN Sunan Gunung Djati Bandung. 
Elvina, L. (2020). WHO Tetapkan Wabah Virus Corona Sebagai Pandemi Global. In Kompas.

He, W., Xu, G., \& Kruck, S. (2014). Online IS Education for the 21st Century . Journal of Information Systems Education.

Khaerul Umam, Perilaku Organisasi, (Bandung: Pustaka Setia, 2010)

Komarudin, \& Prabowo, M. (2020). Persepsi Siswa terhadap Pembelajaran Daring Mata Pelajaran Pendidikan Jasmani Olahraga dan Kesehatan pada Masa Pandemi COVID-19. Majalah Ilmiah Olahraga (MAJORA).

Kusuma, J. W., \& H. (2020). Platform whatsapp grup dan webinar zoom dalam pembelajaran jarak jauh pada masa pandemik COVID-19. Jurnal Ilmiah Pendidikan Matematika, 5(1), 97. https://doi.org/10.26877/jipmat.v5i1.5942

Munir. 2009. Pembelajaran Jarak Jauh Berbasis Teknologi Informasi Dan Komunikasi. Bandung: Alfabeta.

Panigrahi, R., Srivastava, P. R., \& Sharma, D. (2018). Online learning: Adoption, continuance, and learning outcome-A review of literature . International Journal of Information Management.

Maha, E. T., Shazia, S., \& Jehan, A. (2016). Using gamification to develop academic writing skills in dental undergraduate students. European of Journal Dental Education.

Maulah, S., \& Ummah, N. R. (2020). Persepsi Mahasiswa Biologi terhadap Perkuliahan Daring Sebagai Sarana Pembelajaran Selama Pandemi Covid 19. Alveoli: Jurnal Pendidikan

Sugiyono. 2014. Metode Penelitian Kuantitatif dan Kualitatif dan R \& D. Jakarta : Alfabeta.

Yulianingsih, Ika dan Parlindungan, Doby. 2020. Persepsi Mahasiswa Pendidikan Olahraga Terhadap Perkuliahan Daring Selama Pandemi Covid-19. Universitas Muhammadiyah Jakarta. 